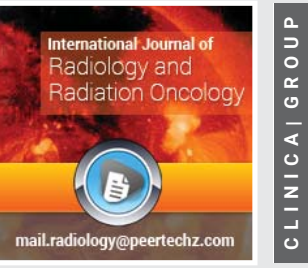

\title{
The impact of Gamma Ray on DNA molecule
}

\author{
Anwar Qasim Ahmed ${ }^{1 *}$, Ali Yahya Salman², Adhraa Baqir \\ Hassan $^{3}$, Ali Abid Abojassim ${ }^{4}$, Hussien Abid Ali Mraity ${ }^{4}$ and \\ Mustafa Amjad Jasim ${ }^{5}$
}

'Department of Ecology, Faculty of Science, University of Kufa, Iraq

2Department of computer techniques, Imam Al-Kadhum College (IKC), Najaf, Iraq

${ }^{3}$ Department of Biology, Faculty of Science, University of Kufa, Iraq

${ }^{4}$ Department of Physics, Faculty of Science, University of Kufa, Iraq

${ }^{5}$ Faculty of languages, University of Kufa, Iraq

Received: 10 February, 2020
Accepted: 16 May, 2020
Published: 18 May, 2020

*Corresponding author: Anwar Qasim Ahmed, Department of Ecology, Faculty of Science, University of Kufa, Iraq, E-mail: ali.alhameedawi@uokufa.edu.iq

https://www.peertechz.com

Check for updates

\section{Aim of the study}

The aim of this review is to provide an overview concerning the effect of one type of ionization radiation (e.g. gamma ray) on DNA considering three axes. The first one considers defining gamma ray, sources of gamma ray and interaction of gamma ray with matters. The second axis focuses on the DNA in term of , while the third one clarify the health effects of the gamma ray with different doses on DNA of human cells. Focusing on the DAN molecule in this review because its importance in two sides. First, the DNA of the human cell is responsible of the function of the specific type of that cell of a given organ. Second, it is responsible of the transferring the gigantic information across new generations.

\section{Introduction}

Ionizing radiations, in general, can lead to a similar effect at the cellular level. However, due to that alpha and beta particles are relatively classified as non-penetrating radiations, the external exposure to such kind of radiation can results in only localized damage to include radiation burns to the skin as an example [1]. By contrast, the gamma radiation and neutrons are most penetrating when compared with alpha and beta radiations, then causing a diffuse damage in the body. The types of damage include radiation sickness, damage of DNA, cell death resulting from the damaged DNA, cancer incidence rather than burns only. In this regards, distinguishing the external exposure from that of internal exposure to radiation is necessary. This is due to the ingested or inhaled radioactive substances depending on the chemical nature of substances that can produce both diffuse and localized internal damage $[2,3]$. Tissue cancer has received the most scientific attention among those effects that the radiation might cause. In this regards, it is well established that radiation, especially the ionizing ones, can destroy the DNA, hence causing cancer and genetic mutations. However, it should be noted that when an individual has induced cancer following a radiation exposure, this depends on the types of damage that the DNA experienced, and also on what portion within the DNA has damaged. Furthermore, it should be considered that the cell line can replicate or not, and the damage is fully fixed, the cell accomplishes the transformations that has the ability to produce the malignancy, how fast the latent cancer improves, and whether the human can survives him long enough until the cancer is diagnosed. Having argued that the ionizing radiation can lead to cancer induction, an individual cancer does not demonstrate specific features which clearly point out whether the radiation have the major role in create and develop the cancer or not. Infectious diseases, on the other hand, are named with reference to the pathogens which are presented in each incident of disease. Cancers are classified in relation to their tissues cells of origins and the nature of the malignant cells instead of a specific causal agents. Consequently, the main evidence concerning the risks from people exposure to radiation are coming from epidemiologic studies that examine incidence of cancer in peoples who were exposed to different doses of radiation. This includes those studies that related to cancer infections among children who exposed to radiation 
in uterus, humans that exposed to high levels of background radiation, nuclear workers, patients exposed to radiation from therapeutic or diagnostic radiations, and also people exposed to radiation from nuclear weapons [3]. The radiation effects on the biomolecules and the DNA in specific can be classified into two categories. The first one is the direct effect and then the second one is the indirect effect. The direct one is resulted from the interaction of radiation itsef directly with the biomolecule. But, the indirect effect can be caused from the interaction of radiation with water molecules existed around the DNA. This would lead to what is known by water hydrolysis. This hydrolysis can yield different types of chemical products. Some of these are known by free radicals while the others which are very toxic such hydrogen peroxide $\left(\mathrm{H}_{2} \mathrm{O}_{2}\right)$. The free radical are very dangerous due their very high reactivity with the surrounding molecules and therefore change their biological and chemical functions $[4,5]$

\section{Gamma-ray}

The gamma ray can be defined as an electromagnetic radiation with an extremely high frequency and therefore of high energy. Generally, it is an ionizing radiation; hence it is a biologically hazardous radiation. Gramm ray are produced, classically, via the decay of unstable nuclei of atoms as they are experiencing a transition from the high energy to a lower energy state that known as gamma ray disintegration/decay. However, gamma ray may also be produced through other processes. The emission of a particle from the nucleus with excited state, gamma ray is emitted. The gamma rays are carrying the excess energy of the partially excited nucleus after a disintegration event occurs. These rays are with a discrete energy and this is characteristic to the specific nuclide considered. So, the corresponding energies can be used for purposes of elements characterization. The gamma-rays are charge less; this means that they do not interact with electrostatic forces as in that of charged particles, which lead to ionization of atoms directly along their path of travel $[6,7]$.

\section{Human DNA}

The DNA or Deoxyribonucleic acid is a biological molecule that comprises the required guidelines for any creature to emerge, grow, live and proliferate. The aforementioned instructions are exist within every cell, and these are handed down from the fathers and mothers to their children [8].

The DNA is generally consisted of certain molecules that known by nucleotides. Every nucleotide comprises a phosphate body, a sugar group together with a nitrogen base. The nitrogen bases are broken down into four types as follows: adenine (A), thymine $(\mathrm{T})$, guanine $(\mathrm{G})$ and cytosine $(\mathrm{C})$ (Figure 1). These bases are built in such order that determines instructions of the DNA, or what is known by the genetic code. The shape of nitrogen structures in a DNA sequence forms genes is resemble to the order of alphabetical letters which can be used to create a word. The latter can be considered as the language of the cell in which it informs the cells how to produce proteins. In this regards, other genre of nucleic acid, which is the ribonucleic acid, or what is known by 'RNA'? The role of it is to transmit the genetic information from DNA into proteins [9].

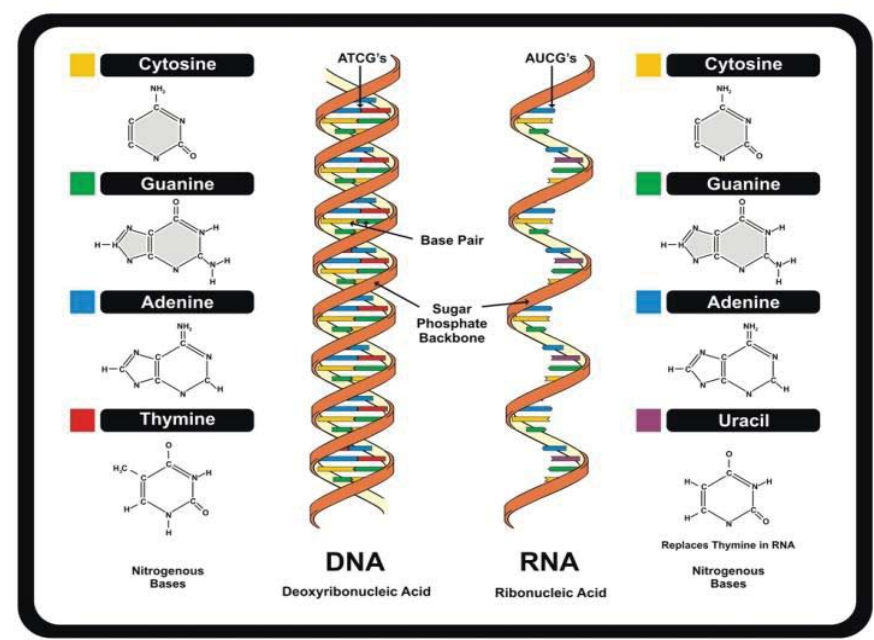

Figure 1: DNA is a double helix formed by base pairs attached to a sugar-phosphate backbone [5]

The whole human being genome includes around 3 $000,000,000$ bases and around 20,000 genes. The nucleotides are combined with each other to create two long spiral strands to form a structure called a double helix. In this context, one could think of the double helix base similar to a stepping ladder, in which the molecules of phosphate and sugar would be the sides of the ladder, whereas its bases would be the rungs. The structures on one strand are paired with the structures on the other strand. To illustrate, this includes adenine pairs with thymine, and guanine pairs with cytosine. The DNA molecule is long. Generally, it cannot fit into a cell without packaging properly. So, in order to suit it inside cells, DNA molecules are curled firmly to generate structures that called chromosomes in which each chromosome includes one DNA molecule. Each living being has twenty three couples of chromosomes, which are found inside the nucleus of the cell.

\section{Characteristics of DNA damage by radiation exposure}

As is was mentioned earlier in this review, the ionizing radiations can directly impact the cellular components or indirectly which impacts the water molecules first. This consequently can cause water-derived free radicals. The corresponding free radicals then react with nearby molecules in a very short-time. This produces a destruction of chemical attachments or oxidation (i.e. adding of oxygen atom) of the attached molecules. The main impact of radiations on the cells is the breakage of DNA. Given that the DNA is consisting of a couple of interrelated and complementary double strands, then the breakage of either a single or both strands may happen. The latter is taken to be biologically extremely crucial. Nevertheless, a great portion of single-strand breakage is normally repairable when compared with the double-stranded nature of the DNA molecule (the two strands supplement each other, so that strand which intact can serve as a framework or a template for repairing of its damaged, opposite strand). Regarding the double-strand breakage, however, rehabilitation is not easy and the reconnecting of broken ends may occur with some errors. This is known by mis-repair which may produce the inducement of mutations, chromosome deviation, or cell 
death [10]. The prominent formation of radiations damage in cells, that survive irradiation, is DNA segments deletion. This kind of damage can be resulted from one of the following reasons: (1) The double-strand breakage of the DNA molecule may not be repaired together with linking the two outer ends and loss of the segment between the breaks or (2) the procedure of cleaning (i.e. enzyme digestion of nucleotides) of the broken ends before rejoining to repair one double-strand break [11].

\section{Conclusion}

Ionizing radiation such that of gamma rays is absolutely hazardous to human beings specifically for those who are in direct contact may be due to their jobs or their health status. This of course due to the high penetration power the gamma ray had. The cell contain a very sensitive biomolecule which the DNA. This DNA is a very critical molecule then efforts must be placed to protect it from being exposed to unnecessary radiation to avoid cancer incidence as one consequences of that exposure.

\section{References}

1. Wing S (2003) Objectivity and ethics in environmental health science. Environ Health Perspect 111: 1809-1818. Link: https://bit.ly/2Lx5II3
2. Tilton EW, Brower JH (2018) Radiation effects on arthropods. In Preservation of food by ionizing radiation CRC Press. 2: 48. Link: https://bit.ly/3cEcGXI

3. Shah DJ, Sachs RK, Wilson DJ (2012) Radiation-induced cancer: a modern view. Br J Radiol 85: e1166-e1173. Link: https://bit.ly/3bCQhIA

4. Santivasi WL, Xia F (2014) lonizing radiation-induced DNA damage, response, and repair. Antioxid Redox Signal 21: 251-259.Link: https://bit.ly/362KivE

5. El-Sayed T, Patel AS, Cho JS, Kelly JA, Ludwinski FE, et al. (2017) Radiationinduced DNA damage in operators performing endovascular aortic repair. Circulation 136: 2406-2416. Link: https://bit.ly/2AqcmgH

6. Knoll GF (2010) Radiation detection and measurement. John Wiley \& Son. Link https://bit.ly/2Wzxj1t

7. Low IM, Azman NZN (2020) Introduction and background. In Polyme Composites and Nanocomposites for X-Rays Shielding (pp. 1-16). Springer, Singapore.

8. Wade N (2007) Genome of DNA pioneer is deciphered. New York Times.

9. Jain M, Koren S, Miga KH, Quick J, Rand AC, et al. (2018) Nanopore sequencing and assembly of a human genome with ultra-long reads. Nature biotechnology 36: 338-345. Link: https://go.nature.com/3g0af

10. Unscear S (2000) Effects of Ionizing Radiation. United Nations, New York, 453487

11. Mould RF (1993) A century of X-rays and radioactivity in medicine: with emphasis on photographic records of the early years. CRC Press.
Discover a bigger Impact and Visibility of your article publication with

\section{Peertechz Publications}

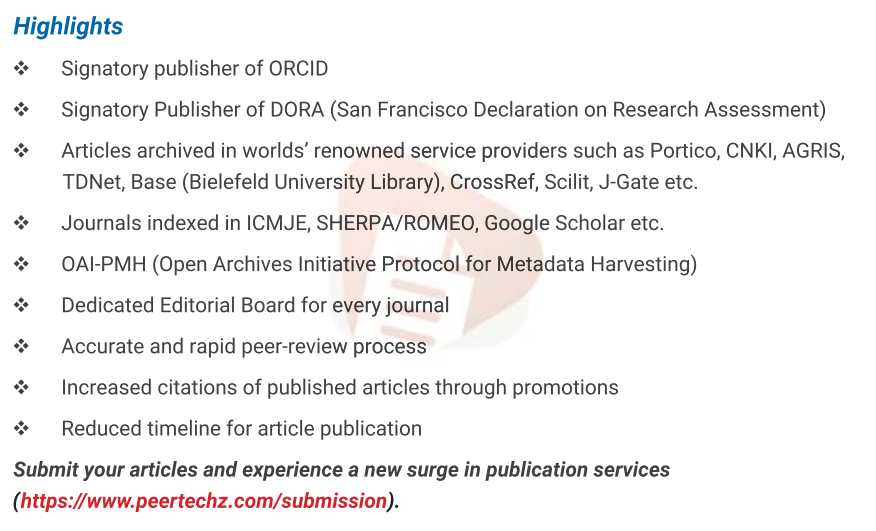

Peertechz journals wishes everlasting success in your every endeavours.

Copyright: ( $) 2020$ Ahmed AQ, et al. This is an open-access article distributed under the terms of the Creative Commons Attribution License, which permits unrestricted use, distribution, and r eproduction in any medium, provided the original author and source are credited. 